DOI: https://doi.org/10.24144/2409-6857.2018.1(51).387-392

УДК: 338. 436. 338. 51

Хомин І.П., Синькевич Н.І.

\title{
ПРАВИЛА ОПОДАТКУВАННЯ Й ФІСКАЛЬНІ ВИЛУЧЕННЯ: ПРОБЛЕМА ВІДПОВІДНОСТІ
}

\begin{abstract}
Розглядається проблема відповідності правил оподаткування та практики фіскальних вилучень. На основі критичного аналізу останньої в поєднанні з аналітичною інтерпретацією фактографічного матеріалу доводиться, щзо в Україні існує суперечність між науково обтрунтованими принципами й правилами оподаткування та практикою справляння податків. Особливо стосовно стимулювання науково-технічного прогресу, технологічного оновлення виробництва, підприємницької виробничої діяльності та інвестиційної активності, оптимальності оподаткування, його обтяжливості для платників, якнайменших витрат зі справляння. Пропонується авторське вирімення иієї проблеми.
\end{abstract}

Ключові слова: оподаткування, принциии, правила, функції, фіскальні вилучення, оптимальність, обтяжливість.

Постановка проблеми. На тлі того, що фундаментальні принципи оподаткування започатковані англійським ученим-класиком А. Смітом ще в 1776 році, зрештою концептуально розвинуті німецьким фінансистом А. Вагнером більш ніж століття тому, можна було би сподіватися на безумовне дотримання рівноправності суб'єктів щодо сплати податків, їхнього точного визначення, зручності для платників, якнайменших витрат зі справляння. Тим паче, коли вони визнані науковцями як ' декларація прав платника'. Та, на жаль, цього не сталося, й нині згадані критерії системи оподаткування, вкупі з його надмірною обтяжливістю для платників, є проблемою, яка має певне наукове, особливо ж практичне значення передусім у контексті фінансовоекономічних методів регулювання розвитку економіки загалом, i фіскальних - у тому числі.

Аналіз останніх досліджень i публікацій. Нині, так само, як більш ніж дев'яносто років тому (1926), актуальні слова 3 рецензії на книгу "'Податки в іноземних країнах" за редакцією В. Твердохлєбова: ' 'Наша податкова система далека від досконалості. Ми весь час шукаємо нових шляхів і не завжди знаємо, що ці шляхи "'заїзджені й сходжені', іншими народами, причому не завжди поїздка на них закінчується сприятливо' $[10$, с. 545$]$.

(c) Хомин Ірина Петрівна, к.е.н., ст. викладач кафедри фінансів ім. С. Юрія, Тернопільський національний економічний університет, м. Тернопіль, тел.: 0979527853, email: xomunka@ @ambler.ru

Синькевич Надія Іванівна, к.е.н., доц.., доцент кафедри обліку та аудиту, Тернопільський національний економічний університет, м. Тернопіль, тел.: 0506544717, email: nadya.synkevych@gmail.com
Та в теорії фінансів із тих же 30 -х років $\mathrm{XX}$ ст. 3 подачі Д. Буткова, який стверджував, що "'марксизм дуже мало проник у галузь фінансів, де все ще міцно засіли буржуазні апологети, давно спростовані в економіці, які протягують через фінансову науку чужі марксизму концепції в ту саму економіку" [10, с. 547], на понад півстоліття відкинули '’буржуазний суб'єктивізм" та '”формально-догматичний підхід”, унаслідок чого будь-яка критика чинного на той час оподаткування була неможлива. I лише в 1991 році такі ярлики, навішувані на праці відомих учених, уперше зняли відомі українські фінансисти В. Суторміна, В. Федосов, В. Андрущенко, проламавши ідеологічне табу своєю монографією [3], й грунтовно висвітливши світовий досвід фіскального регулювання ринкової економіки.

Водночас, попри те, що поряд із ними вирішенню окресленої проблеми присвятили свої праці інші авторитетні вчені, на практиці вона не тільки не зникла, але й поглибилася. Й із ',позиції теоретико-методологічноих постулатів, - як зауважує Ю. Ляшенко, - оподаткування в Україні не відповідає основним вимогам щодо побудови податкових систем демократичних правових держав, які є науково обгрунтованими i перевіреними світовим досвідом їх формування та функціонувння' '[5, с. 151]. В той час, як вона "має спиратися на довгострокову програму економічного й соціального розвитку України, 3 урахуванням основних засад якої мають формуватися пріоритетні напрями ...' [4, с. 553].

Отож саме націленість вітчизняної податкової системи на зростання фіскальних вилучень $\epsilon$, на нашу думку, головною частиною наразі невирішеної наукової та практичної проблеми, що унеможливлює економічний i соціальний розвиток України. 
Формулювання цілей статті. Виходячи 3 цього, метою й завданнями статті визначено узагальнення емпіричних даних і доведення на їхній основі як необхідності, так і можливих шляхів удосконалення оподаткування суб'єктів господарювання 3 метою посилення відповідності фіскальних вилучень правилам оподаткування й підвищенню його ролі в стимулюванні розвитку економіки України.

Опис основного матеріалу дослідження. Поза тим, що вітчизняні вчені стосовно України наводять доволі широку амплітуду значень податкового навантаження, яке 3 урахуванням внесків до Пенсійного фонду, на їхню думку, є оптимальним у межах від 16,7-17 \% до 29$30,5 \%$ ВВП, в т. ч. основних податків $-22,6 \%$, очевидно, що фактичні фіскальні вилучення не відповідають цим правилам. Тому-то втрати ВВП за 1998-2013 роки становили близько 3 трлн грн (у середньому 200 млрд грн щороку), а номінальні надходження могли би зрости при рівні податкового навантаження $30,5 \%$ приблизно на 250000 млн грн у розрахунку на рік $[1$, с. $66,70,73,75]$.

I при всіх сумнівах в достовірності цих розрахунків уже те, що в в кінці 2014 року були прийняті зміни до Податкового кодексу України, а в наступному (грудень, 2015) вони взагалі стали революційними, особливо щодо єдиного соціального внеску на соціальні заходи, $\epsilon$ підстави для об'єктивного висновку, що податкове навантаження наразі далеке від оптимального. Отож і нині на часі ідея, яку висунув ще Дж. С. Мілль, указуючи, що за допомогою податків треба ліквідувати недосконалість природних відносин. Пізніше іiі підтримував А. Вагнер - розробник дев'яти основних правил оподаткування, які витікають із принципу справедливості, за яким має збільшуватися обкладання багатих (рис. 1).

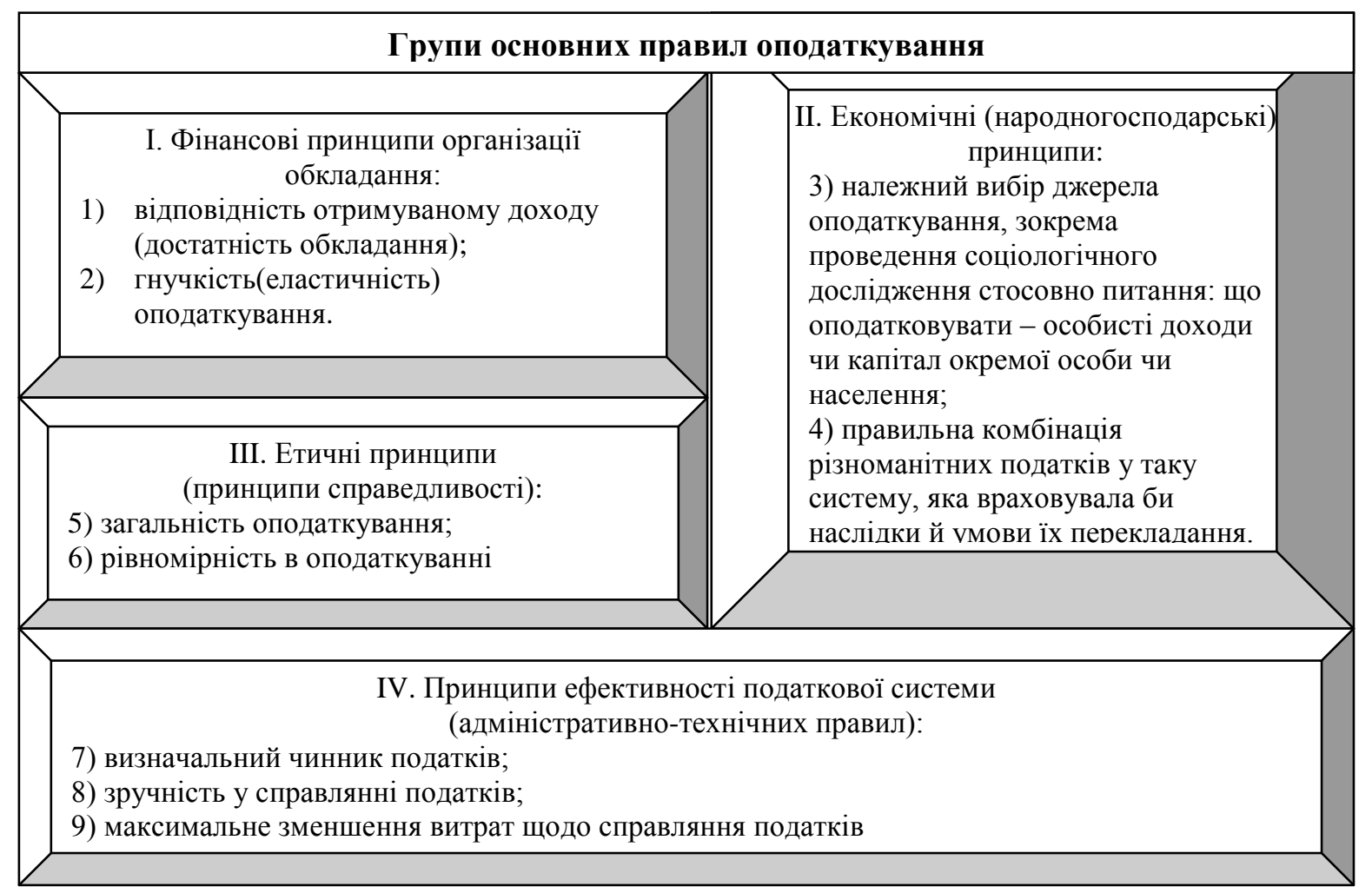

Рис. 1. Дев'ять основних правил оподаткування А. Вагнера*

* Розроблено авторами на основі опраџювання [10, с. 165].

Саме ці правила донині $є$ методологічною основою більшості досліджень у фінансовій науці, не виключаючи й цієї статті, а окремі $з$ них ніби виходять із майбутнього, як ото необхідність ' 'нагляду за дотриманням принципів екології', [10, с. 163], вперше обгрунтована А. Вагнером, опісля доповнена й конкретизована 'податками Пігу", які "накладаються 3 метою інтерна- лізації” [10, с. 124], тобто включаються в затрати виробництва тих видів продукції, що завдають шкоду екології.

Проте на практиці не тільки немає збільшення обкладання багатих, але й екологічний податок, вкупі 3 рентними платежами, які власне й сплачують такі суб'єкти господарської діяльності, настільки мізерні, що говорити про 
їхній вплив на”, дотримання принципів екології”, наразі не доводиться.

Водночас, як виглядає за нинішніх умов закон А. Вагнера щодо "'розширення обсягу державної діяльності', який він сформулював на основі ідеї, що "'втручання держави в господарське життя визначається конкретними умовами часу й місця", а тому '”темпи збільшення видатків можуть перевищувати темпи зростання національного продукту", [10, с. 163-164], є спірним.
Принаймні стосовно України тепер мова повинна йти не про розширення, а про звуження '”бсягу державної діяльності', Зважаючи на надмірно високий відсоток вилучення доходів підприємств до Державного бюджету - 3 одного боку, а потім порівняно великі, та все ж недостатні грошові потоки в зворотному напрямі, які не справляють помітного впливу на розвиток економіки (табл. 1).

Співвідносність ВВП, податкових вилучень, номінальної

Таблиця 1 й реальної зарплати в Україні за 2005-2016 роки*

\begin{tabular}{|l|c|c|c|c|c|c|c|c|}
\hline Показники/Роки & $\mathbf{2 0 0 5}$ & $\mathbf{2 0 1 0}$ & $\mathbf{2 0 1 1}$ & $\mathbf{2 0 1 2}$ & $\mathbf{2 0 1 3}$ & $\mathbf{2 0 1 4}$ & $\mathbf{2 0 1 5}$ & $\mathbf{2 0 1 6}$ \\
\hline ВВП, млн грн & 441452 & 1120585 & 1349178 & 1459096 & 1522657 & 1419116 & 1988544 & 2383182 \\
\hline $\begin{array}{l}\text { Податкові } \\
\text { вилучення, } \\
\text { млн грн }\end{array}$ & 98065 & 234448 & 334692 & 360567 & 353968 & 367512 & 507636 & 650782 \\
\hline $\begin{array}{l}\text { Відсоток } \\
\text { вилучення, \% }\end{array}$ & 22,2 & 20,9 & 25,7 & 25,6 & 23,2 & 25,9 & 25,6 & 27,3 \\
\hline $\begin{array}{l}\text { Індекс реальної } \\
\text { зарплати, \% }\end{array}$ & 120,3 & 110,2 & 108,7 & 114,4 & 108,2 & 93,5 & 79,5 & 109,0 \\
\hline
\end{tabular}

*Розраховано авторами за даними Держстату Украӥни

Так, якщо відсоток податкових вилучень зріс проти рівня 2005 року на 5,1 в. п., то вирівняні способом найменших квадратів індекси реальної зарплати працівників в Україні демонструють тренд зниження за цей період у середньому на $2 \%$ щорічно. Отож маємо суперечність не тільки щодо відповідного принципу оподаткування А. Сміта, але й опосередковано - зменшення чисельності населення за цей період на $(46,0-$ 42,6) 3,4 млн осіб.

Не слід також забувати про таке правило, як максимальне зменшення витрат щодо справляння податків, сформульоване А. Вагнером, бо на практиці воно не менш актуальне, ніж доповнення в Законі України « Про систему оподаткування», зокрема щодо «стимулювання науковотехнічного прогресу, технологічного оновлення виробництва, стимулювання підприємницької виробничої діяльності та інвестиційної активності». Адже в Податковому кодексі вони не втілені. Приміром, основні податки - ПДВ, податок на прибуток, - не витримують критики насамперед під цим аспектом, зважаючи на громіздкість і надмірну затратність складання, отже й перевірок достовірності фіскальної звітності. Причому й нині актуальне міркування В. Петті, котрий однією 3 причин, які роблять обтяжливим оподаткування, вважав те, що в його системі «Е багато посад, котрі повністю виконуються помічниками за незначну плату, тоді, як їхні начальники отримують у десять разів більше, хоча вони зовсім не знають ні того, чого не було зроблено, ні того, що потрібно було зробити в тому чи іншому випадку». А стосовно самої системи звертав увагу на «підозру значної частини населення, що обкладання надто велике, зібрані суми розкрадаються, неправильно витрачаються, або вони нерівномірно справляються й розподіляються» [7, с. 428-434].

Не кажучи вже про те, що жоден із податків, які сплачують підприємства до бюджету, не стимулює науково-технічного прогресу, технологічного оновлення виробництва, підприємницької виробничої діяльності та інвестиційної активності розвитку, оскільки така функція випала із вітчизняної системи оподаткування, тому вони можуть розглядатися радше в дусі Д. Рікардо, як «велике зло, котре полягає не стільки в тому, що вони справляються 3 тих чи інших об'єктів, скільки в їхній негативній дії в цілому», позаяк «ведуть до зменшення нагромадження та збільшують витрати виробництва» [6, с. 129].

Що підтверджується насамперед стосовно аграрного сектору, якщо прийняти до уваги його традиційний розгляд як донора економіки. Зокрема, якщо в передвоєнний 1940 рік колгоспи України сплатили до бюджету 1,8 млн крб. прибуткового податку, то в 1960 році вже 315 млн крб. Отож навіть на тлі загального дев'ятикратного зростання доходів бюджету за цей період із 835,9 до 7690,5 млн крб., збільшення податків із колгоспів виглядає надмірним, особливо в порівнянні 3 тим, що 
платежі промисловості й будівництва (за період 1940-1977 роки) зросли в 43,5 разів, а сільському господарства - в 517,5 разів.

Й це ніяк не може бути визнаним відповідним не те що принципу справедливості в дусі А. Сміта, але й навіть 3 огляду на пояснення: «Міра участі колгоспів у формуванні загальнодержавних фондів грошових коштів на різних етапах визначалася ... виходячи 3 конкретних економічних завдань країни» та «швидкими темпами зростання продуктивності праці, що зумовлює значне зниження собівартості ... й відповідно підвищення рентабельності виробництва» [11, с. 678-679], бо останнє було радше бажаним, ніж фактичним.

За нинішніх умов прикладом, який підтверджує наведений перед тим висновок Д. Рікардо, може бути колишній фіксований сільськогосподарський податок (тепер єдиний податок), який не тільки сплачують збиткові господарства, але він сам призводить до збільшення збитку, унеможливлюючи в них будь-які сподівання на формування фінансових ресурсів розвитку, позаяк включається до витрат виробництва, а не покривається 3 прибутку. Відтак думається, що при оподаткуванні доходів у першу чергу фермерів, а тим більш особистих селянських господарств, слід ураховувати витрати, пов'язані 3 їхньою виробничою діяльністю.

При цьому для уникнення суб'єктивізму при визначенні оподатковуваного доходу доцільно встановити перелік типових витрат, які дрібні товаровиробники можуть відносити на його зменшення, наприклад придбання пальномастильних матеріалів, міндобрив, отруто-хімікатів, комбікормів тощо, оплату залученої до виконання робіт у рослинництві й тваринництві робочої сили. Безумовно, ці витрати мають бути документально підтвердженими, що за сучасних умов не складатиме особливих труднощів, зважаючи на можливість отримання касових чеків чи інших платіжних документів і спрощення контролю їхньої достовірності завдяки відо-браження даних за допомогою електронних засобів.

3 іншого боку, це допоможе вивести з тіні доходи, які приховуються від оподаткування окремими постачальниками засобів виробництва для таких сільськогосподарських товаровиробників, а якщо до цього додати підтвердження виплати заробітної плати через банки, то й доходів значної частини тимчасових і залучених до цих робіт працівників.

Загалом же податкова система має відповідати економічній доктрині держави та науково обгрунтованій фінансовій стратегії й тактиці розвитку, на необхідності розроблення якої наголошують В. Федосов, В. Опарін й інші вчені, вказуючи, що трансформація фінансової системи в умовах перехідної економіки повинна відбуватися комплексно, бо часткові зміни в їі окремих сегментах $\epsilon$ i будуть мало результативними [8]. В такому контексті це можна перш за все віднести до оподаткування, недоліки якого асоціюються 3 неводом, що мав би в першу чергу із усього різнорозмірного розмаїття "риби" витягувати на палубу сейнера ті особини, які мають відповідні параметри, а не всіх поспіль.

3 огляду на це заслуговує на увагу запропонована науковцями модель бюджетної політики, в якій зроблено спробу поєднати, виходячи 3 положень економічної архітектоніки, соціальні та інноваційні бюджетні складові й ідеї реформування податкової системи України в цьому руслі [9]. Бо навіть після останніх змін Податкового кодексу України непоодинокими $є$ випадки, коли більші "рибини" перескакують через верхню линву невода, чи втікають попід нижньою, або відбиваються від його стінок i відпливають убік від оподаткування, як-от при фіктивному експор-ті й отриманні внаслідок цього, замість сплати податків незаконного відшкодування ПДВ.

Разом 3 тим проблемою, від вирішення якої значною мірою залежить розвиток економіки, $є$ переорієнтація оподаткування 3 каральної функції на стимулюючу, на чому акцентує увагу О. Десятнюк. Адже загалом виходить, що одні підприємства розплачуються за '”податкові ризики й загрози", зумовлені іншими, внаслідок відсутності в Україні '"ризикоорієнтованої системи адміністрування податків'”[2, с. 276]. Бо якби було інакше, то видається, що хронічне перевищення обсягу імпортних операцій над експортними було би неможливим.

Наразі ж навіть в аграрному секторі, де ситуація загалом протилежна, тож виходить, що саме він покриває своєю валютною виручкою негативне сальдо зовнішньоторговельного балансу, певною мірою спокутуючи чужі гріхи, виглядаючи відтак покараним податковою системою майже відповідно 3 висновком М. Яснопольського, зробленим ним у кінці XIX ст.: ' Виробники товарів, які йдуть на експорт й обкладаються митними зборами, отримують перевагу порівняно з виробниками внутрішнього ринку' [10, с. 192], правда, з тією різницею, що це стосується нині головно зернотрейдерів чи агрохолдингів, а не всіх підприємств галузі (табл. 2). 
Таблиця 2

Групування аграрних підприємств за фінансовими результатами*

\begin{tabular}{|l|c|c|c|c|c|c|}
\hline Показники/роки & 2010 & 2011 & 2012 & 2013 & 2014 & 2015 \\
\hline Частка прибуткових, \% & 69,6 & 83,5 & 78,6 & 80,3 & 84,7 & 88,9 \\
\hline $\begin{array}{l}\text { Їхній прибуток, } \\
\text { млн грн }\end{array}$ & 22094,9 & 30182,3 & 33570,1 & 26186,6 & 51668,0 & 127360,1 \\
\hline Частка збиткових, \% & 30,4 & 16,5 & 21,4 & 19,7 & 15,3 & 11,1 \\
\hline Їхній збиток, млн грн & 4841,3 & 4915,3 & 6841,7 & 11260,9 & 30254,6 & 25081,1 \\
\hline
\end{tabular}

*Розраховано авторами за даними Держстату Украйни

Зокрема за зведеними показниками ховається той факт, що в окремі роки частка збиткових підприємств коливалася в околі від майже третини $(2010$ р.) до трохи більше десятої частини (2015р.). Причому з урахуванням того, що нерентабельні господарства в основному $є$ платниками єдиного податку та соціального внеску, виходить, що вони сплачують їх усупереч податковій аксіомі фінансової теорії неприпустимості цього за рахунок зменшення власного капіталу суб'єкта господарювання

Висновки й перспективи досліджень розглянутої проблеми. На жаль, наразі скидається на те, що податкова практика базується не на наукових засадах, а на тривіальному положенні, відомому ще 3 часів Середньовіччя: '’Бери, де можна, і якомога більше'. Бо ні один податок, установлений за Податковим кодексом України, не має достатньо вираженої стимулюючої функції.

Радше навпаки, всі вони сукупно протидіють розвитку, а значна частина суб'єктів господарювання навіть змушена сплачувати податки за рахунок капіталу, оскільки їхня діяльність нерідко $є$ хронічно збитковою впродовж доволі тривалого періоду, у зв'язку з чим в їхньому балансі власний капітал підприємства нерідко навіть фігурує як віртуальна від'ємна величина.

Через що стимулююча функція оподаткування стосовно інноваційного розвитку підприємств практично знівельована, а головною, як видається, стала каральна, нерідко нагадуючи підхід, протилежний до афоризму, висловленого римським імператором Тиберієм (42 р. до н. е.-37 р. н.е.), за яким "хороший пастух має стригти своїх овець, а не різати їх". Тому для вирішення проблеми відповідності правил оподаткування 3 практикою фіскальних вилучень необхідно якнайшвидше перейти до втілення в Податковому кодексі України основоположних принципів соціальної справедливості, рівнонапруженості, економічної ефективності, стабільності, гнучкості, які давно вироблені фінансовою наукою.

Та це лише частина заходів, які можуть прислужитися вирішенню окресленої в статті проблеми. Таким чином, зважаючи на іiі вагомість і складність, дальші дослідження в цьому напрямі будуть перспективними.

\section{ПЕРЕЛІК ВИКОРИСТАНИХ ДЖЕРЕЛ}

1. Вдовиченко А. М. Податкове навантаження і темпи економічного зростання в Україні: у пошуках раціонального співвідношення /А. М. Вдовиченко, Г. В. Орос //Економіка України, 2014. - № 8. - С. 61-78.

2. Десятнюк О. М. Моніторинг податкових ризиків: теорія та практика: монографія /О. М. Десятнюк. Тернопіль: ТНЕУ, 2009. - 312 с.

3. Держава - податки - бізнес (зі світового досвіду фіскального регулювання ринкової економіки): монографія /Суторміна В. М., Федосов В. М., Андрущенко В. Л. - К.: Либідь, 1992. - 328 с.

4. Лисяк Л. В. Бюджетна політика у системі державного регулювання соціально-економічного розвитку України: моногр. /Л. В. Лисяк. - К.: ДННУ АФУ, 2009. - 600 с.

5. Ляшенко Ю. І. Формування бюджетних коштів України в умовах ринкової трансформації економіки (теорія і практика): монографія /Ю. І. Ляшенко. - Ірпінь.: Академія ДПС України, 2003. - 200 с.

6. Риккардо Д. Начала политической экономии и налогового обложения. Избранное /Д. Риккардо; [пер. с англ.; предисл. П. Н. Клюкина]. - М.: Эксмо, 2007. - 960 с.

7. Сперанская Л. Н. Экономические взгляды У. Петти /Л. Н. Сперанская. - М.: Мысль, 1987. - Т. 1. - 606 с.

8. Федосов В. Фінансова реструктуризація в Україні: проблеми і напрями: монографія /В. Федосов, В. Опарін, С. Льовочкін //За наук. ред. В. Федосова. - К.: КНЕУ, 2002. - 387 с.

9. Фінанси України: інституційні перетворення та напрям розвитку /за ред. І. Я. Чугунова. - К.: ДННУАФУ, 2009. $-848 \mathrm{c}$.

10. Фінансова думка України. Хрестоматія /автори-упорядники С. І. Юрій, С. В. Льовочкін, В. М. Федосов, П. І. Юхименко. за наук. ред.: д.е.н., проф. В. М. Федосова.- К.: Кондор, Тернопіль: Економічна думка, 2010. У 3 т. - T. 3. - Ч. II. -734 c. 
11. Фінансова думка України: Монографія /П. І. Юхименко, С. В. Льовочкін, В. М. Федосов, С. І. Юрій; за наук. ред. д.е.н., проф. В. М. Федосова. - К.: Кондор, Тернопіль: Економічна думка, 2010. - У 3 т. - Т 1. $687 \mathrm{c}$.

\section{REFERENCES}

1. Vdovichenko, A. M. (2014). Podatkove navantazhennia i tempi ekonomichnogo zrostannia v Ukraini: u poshukakh ratcionalnogo spivvidnoshennia [Tax burden and pace of economic growth in Ukraine: in search of a rational ratio]. Ekonomika Ukraïni - Economic of Ukraine, 8, 61-78. [in Ukrainian].

2. Desiatniuk, O. M. (2009). Monitoring podatkovikh rizikiv: teoriia ta praktika: monografiia [Monitoring of Tax Risks: Theory and Practice: Monograph]. Ternopil: TNEU. [in Ukrainian].

3. Sutormina V. M., Fedosov V. M., Andrushchenko V. L. (1992). Derzhava - podatki - biznes (zi svitovogo dosvidu fiskalnogo reguliuvannia rinkovoï ekonomiki): monografiia [State - Taxes - Business (from the world experience of fiscal regulation of a market economy): monograph]. - Kiev: Libid. [in Ukrainian].

4. Lisiak L. V. (2009). Biudzhetna politika u sistemi derzhavnogo reguliuvannia sotcialno-ekonomichnogo rozvitku Ukraïni: monografiia [Budget policy in the system of state regulation of socio-economic development of Ukraine: monograph]. Kiev.: DNNU AFU. [in Ukrainian].

5. Liashenko Iu. I. (2003). Formuvannia biudzhetnikh koshtiv Ukraïni v umovakh rinkovoï transformatciï ekonomiki (teoriia i praktika): monografiia [ Formation of budgetary funds of Ukraine in the conditions of market transformation of economy (theory and practice): monograph]. Irpin.: Akademiia DPS Ukraïni. [in Ukrainian].

6. Rikkardo D. (2007). Nachala politicheskoi ekonomii i nalogovogo oblozheniia. Izbrannoe [The beginning of political economy and taxation. Favorites]. Moskow: Eksmo. [in Russian].

7. Speranskaia L. N. (1987). Ekonomicheskie vzgliady U. Petti [The Economic Views of W. Petty]. (Vol.1). Moskow: Mysl, [in Russian].

8. Fedosov V. (2002). Finansova restrukturizatciia v Ukraïni: problemi i napriami: monografiia [Financial restructuring in Ukraine: problems and directions: monograph]. Kiev: KNEU. [in Ukrainian].

9. Chugunov I. Ia. (2009). Finansi Ukraïni: institutciini peretvorennia ta napriam rozvitku [Finance of Ukraine: Institutional Transformation and Development Direction]. Kiev: DNNUAFU. [in Ukrainian].

10. Fedosov V. M. (2010). Finansova dumka Ukraïni. Khrestomatiia [Financial Opinion of Ukraine. Reader]. Kiev: Kondor, Ternopil: Ekonomichna dumka. [in Ukrainian].

11. Fedosov V. M. (2010). Finansova dumka Ukraïni: Monografiia [Financial Opinion of Ukraine: Monograph]. Kiev: Kondor, Ternopil: Ekonomichna dumka. [in Ukrainian].

Одержано 13.03. 2018 p. 